\title{
Itinéraires Itinéraires
}

Littérature, textes, cultures

2016-2 | 2017

Livre, sérialité et transmédialité

\section{Reconsidering Narrative Closure in the Eighteenth Century: Transfictionality in Mauvillon's Continuation of Prévost's Mémoires d'un honnête} homme

Reconsidérer la clôture narrative au dix-huitième siècle : la transfictionnalité dans la continuation des Mémoires d'un honnête homme de Prévost écrite par Mauvillon

\section{Benjamin H. Baker}

\section{CpenEdition}

\section{Journals}

Electronic version

URL: http://journals.openedition.org/itineraires/3473

DOI: $10.4000 /$ itineraires.3473

ISSN: 2427-920X

Publisher

Pléiade

Electronic reference

Benjamin H. Baker, « Reconsidering Narrative Closure in the Eighteenth Century: Transfictionality in Mauvillon's Continuation of Prévost's Mémoires d'un honnête homme », Itinéraires [Online], 2016-2 | 2017, Online since 11 May 2017, connection on 02 October 2020. URL : http:// journals.openedition.org/itineraires/3473 ; DOI : https://doi.org/10.4000/itineraires.3473

This text was automatically generated on 2 October 2020.

Itinéraires est mis à disposition selon les termes de la licence Creative Commons Attribution - Pas d'Utilisation Commerciale - Pas de Modification 4.0 International. 


\title{
Reconsidering Narrative Closure in the Eighteenth Century: Transfictionality in Mauvillon's Continuation of Prévost's Mémoires d'un honnête homme
}

\author{
Reconsidérer la clôture narrative au dix-huitième siècle : la transfictionnalité \\ dans la continuation des Mémoires d'un honnête homme de Prévost écrite \\ par Mauvillon
}

Benjamin H. Baker

1 If the phenomenon of transfiction depends on transgressing borders between narratives, as Richard Saint-Gelais has argued, it is essential to understand how those boundaries functioned differently in the past than they do now, if we are to use transfiction as a category of analysis for fictional narratives of various time periods. Modern readers' experience of transfictionality depends on robust boundaries separating works of fiction: so long as narratives remain within the bounds of the works that give them textual expression, we remain in the realm of normal fiction, but when narrative material crosses those boundaries we enter the realm of transfiction. Saint-Gelais asserts that the crossing of boundaries forms the crux of transfictionality, and proposes three possible sources of transfictionality: "l'indépendance matérielle des textes ; celle des récits ; l'intervention d'un écrivain distinct de l'auteur original" (2011: 24). ${ }^{1}$ At first glance, the source of the transfictional relationship between the versions of Mémoires d'un honnête homme by Antoine François Prévost and Éléazar de Mauvillon appears to be the intervention of two authors and the presence of a boundary between the first and second installments separating Prévost's text from Mauvillon's. However, as my analysis will show, the transfictionality of this eighteenth-century text derives from the coexistence of two narrative structures within a single work. Mauvillon's modifications to the relationship between dispositive and narrative boundaries in 
Prévost's text, initiated via additions to the first installment, written by Prévost, and completed in the second installment, entirely written by Mauvillon, enable a reformulation of the narrative structure of the Mémoires which we understand as transfictional. Material boundaries and transfers of authorship do not suffice to create transfictionality in the eighteenth century because in the pre-Revolutionary period, authors had no more claim on their products than any artisan: once narrative ideas took textual form, they were available to others to use as they wished. Mere appropriation of another writer's fictional material, even in a new publication, did not create transfictionality.

2 In the absence of boundaries established by modern copyright law, I argue that eighteenth-century texts-like Mauvillon's continuation of Prévost's work-became transfictional through the manipulation of narrative structure. Instead of passing off his work as that of the original author, Mauvillon extended it beyond its original boundaries and inserted material into the original text, thus transforming Prévost's narrative structure. These insertions are crucial to making the text transfictional. Whereas adding to the original text violates no boundaries in the eighteenth century, Mauvillon's alterations superimpose a new narrative structure onto Prévost's text. Mauvillon's version of the Mémoires falls outside the modern transfictional binary: it is neither an independent work containing elements belonging to a separate fiction, and therefore transfictional, nor a mere continuation, and therefore not transfictional, but rather a transfictional continuation that transforms Prévost's original text.

\section{Transfictionality as a Function of Authorship, Copyright, and Disposition}

3 Since the early twentieth century, technological innovation has exponentially multiplied transmedial and transfictional phenomena associated with serialized narrative, from podcasts to fan fiction. Thus, we are right to think that our society presents a unique conjunction of these phenomena, as Jenkins (2006) has suggested. However, transfictionality is not new, nor is its association with serialization. Rather, now as in the past, these phenomena occur in certain ways at different times because of the evolving relationship between the producers of texts and their audiences, as mediated by modes of production and distribution. The nineteenth century provides evidence of serialized narrative fiction predating electronic broadcasting, and of the link between serialization and transfictionality (e.g., posthumous continuations of Dickens' Edwin Drood). In fact, publication in installments has been a mode of production of narrative fiction and a source of transfictional phenomena since the beginning of the seventeenth century. ${ }^{2}$ Prior to widespread regular serialization in the nineteenth century, narrative prose fiction often appeared in installments long enough to stand as independent works, which were separated by periods ranging from months to years, and these texts were commonly continued by individuals other than the original authors. Such works can be called periodical to distinguish them from serialized works, which follow a faster rhythm of shorter installments. ${ }^{3}$ Readers eagerly awaited each part of Urfés Astrée and its posthumous continuation, and characters from the unauthorized continuation of Cervantes' Don Quixote by the pseudonymous Alonso Fernández de Avellaneda reappeared in Cervantes' continuation. Medieval texts seem transfictional almost by definition, given that what matters is the originality of 
arrangement of shared fictional material into a particular form (Blaise 2007). Many critics see the proliferation of sequels, continuations, and fragments in the eighteenth century as a sign of resistance to closure, suggesting that transfictionality may have been a more fundamental element of the underlying conditions of fiction during that period than it is today. In some cases, authors continued their own works themselves; ${ }^{4}$ some works were continued by other authors; ${ }^{5}$ and some were continued both by unauthorized writers and the original ones. ${ }^{6}$. These three scenarios suggest a resemblance between the eighteenth-century conception of the artistic whole and the modern idea of transfictionality. Modern texts, transfictional or not, rely on the modern concept of intellectual property, assuming the integrity of each work, and allowing modern writers (who avoid copyright infringement) to make transfictional texts without degrading their own right to the new intellectual property thus created.

How might evolving conceptions of authorial ownership in eighteenth-century France have shaped readers' perception of Mauvillon's continuation? The idea of what constituted a complete work was not what it is today. Scholars have noted the limits of theories of closure such as Kermode's, which fail to adequately account for the specificities of pre-nineteenth-century prose fiction. ${ }^{7}$ Works of prose fiction remained open to continuation by the original author or others. Whereas modern copyright law associates authors' identities with the identity of their artistic productions (cf. Hirschfield 2001: 30), that association was evolving during the eighteenth century, away from a split between author and copyright owner. The distinction between authorship and the right to control the production and distribution of an imaginative work under the ancien régime through the practice of privilège (the exclusive right to publish a given printed text) was the legal reflection of a conceptual distinction between the ideas that make up a narrative and their realization in material, commercial form as texts. Before post-Revolutionary French law recognized a privileged connection between writers and the texts they produced (droit d'auteur, roughly equivalent to copyright in the English-speaking world), owners of privilège (usually booksellers or printers) could hire anyone to write a continuation (cf. Cleveland). Thus, the conceptual boundaries between original texts and their continuations were less rigid prior to the advent of modern copyright laws then they generally are today, and all prose fiction produced under the system of privilège was potentially transfictional.

5 The difficulty modern readers face in trying to understand transfictionality in the precopyright era is manifest in Genette's distinction between the authorized continuation of an unfinished work and the commercially-motivated suite (1982: 222-23). SaintGelais has noted the insufficiency of this distinction, calling for further study of earlier transfictional texts; while he mentions several eighteenth-century works, he fails to address the influence of the modes of publication and distribution of the time on their potential transfictionality (2011: 40). Mauvillon's continuation of Prévost's Mémoires provides a useful case study, but scholarship on the Mémoires has yet to be informed by transfictional theory. ${ }^{8}$ The availability of privilège for new editions meant that a continuation such as Mauvillon's would have been both a "new" work, in that it was eligible for a privilège, and the "same" work, in that it completed an unfinished narrative fiction. ${ }^{9}$ By inserting new material into Prévost's text and extending it beyond its original dimensions, Mauvillon crossed one of the boundaries delimiting the zone of transfiction. 
6 The relationship between Prévost's version (1745) and Mauvillon's (1753) is complex: neither is necessarily whole nor incomplete, nor did Mauvillon assert a full claim to his expanded continuation of Prévost's preexisting text. Mauvillon could have claimed the work without sacrificing anonymity (by presenting the work as published by M. de $\mathrm{M}^{* * * *}$ and omitting references to the original author and the new manuscript). Conversely, had he intended to avoid claiming credit, he could have omitted any selfreference. However, Mauvillon's title page does both, referring to the text as Mémoires d'un honnête homme, revîs [sic], corrigés, augmentés d'un second volume, et imprimés sur un nouveau manuscrit de l'auteur, publié par M. de $M^{* * * *} .{ }^{10}$ In addition, rather than make the relationship between the original edition and the new one explicit by keeping the original "avant-propos de l'éditeur" (editor's foreword) intact and supplementing it with a new one, Mauvillon inserts material, easily overlooked by an unwary reader, into the original foreword. Finally, the credit given the original author by mentioning the new manuscript is undercut by the emphasis on the role of the new "editor" created by the description of the new edition as revised, corrected, and expanded. ${ }^{11}$ These contradictions suggest that Mauvillon felt neither obligated to preserve Prévost's authorial claim, nor free to act as if this publication were a seamless continuation of the previous one. The absence of an authorized continuation by Prévost suggests that pragmatism alone cannot explain the adoption of a new title page: Mauvillon could have ridden the success of the first installment without drawing the reader's attention to its discontinuity with the second. The dual indeterminacy of authorial ownership and dispositive boundaries provides a more complete explanation. At a time when unpredictable publication rhythms and loose claims of authorial ownership rendered modern transfictionality practically ineffective, Mauvillon executed a dual strategy of authorial self-presentation and textual framing to draw a transfictional boundary legible in the eighteenth-century context, creating a boundary that he then crossed, thereby increasing the interest of his work.

7 The transfictional relationship between Mauvillon's and Prévost's versions of the Mémoires is marked by the manipulation of narrative and dispositive boundaries, discussed here using Ugo Dionne's concept of disposition. ${ }^{12}$ Modern readers expect impermeable boundaries between fictional works. We derive pleasure from recognizing the same character in a different work: boundaries matter. By contrast, eighteenthcentury readers often encountered the continued adventures of a character in a continuation of the same work, because modes of production and distribution rendered boundaries between works uncertain, decreasing the contrast between the renewed appearances described above. The uncertainty of these external boundaries facilitates intermittent coordination between narrative and dispositive structures. The sophistication of the resulting narration, constrained by the modes of production and distribution of the time, largely depends on the imagined eventual whole "work" that writers encouraged readers to construct mentally as they progressed through the text. ${ }^{13}$ Dionne's ideas about disposition help us to see how Prévost and Mauvillon use a text that is largely the same to encourage their readers to construct substantially different mental images of the eventual whole. For example, the first installment of the Mémoires (all that Prévost wrote, published in 1745) ends at the protagonist's deathbed, providing an intense co-ordination of dispositive and narrative structures signaling an apparently impermeable boundary. Yet closer analysis reveals a dialectical narrative structure left open at this dispositive boundary, enabling a potential (but never realized) expansion by Prévost. Yet, when Mauvillon actualized this possibility, rather 
than continuing in the way prefigured by the relationship between dispositive and narrative structures in the original version, he shifted that relationship by inserting new material into Prévost's text.

8 The ability of a single text to accommodate two different narrative structures demonstrates the readiness of contemporaneous readers to dissociate content and form. Readers were neither unaware that different parts of the "same" work might be written by different writers, nor indifferent to the change of authorship. Indeed, transfictionality depended on signals such as putting on the role of "editing" a new edition, as Mauvillon does. Furthermore, the apparent contradiction between Prévost's failure to dispute Mauvillon's continuation of the Mémoires and his vocal rejection of the apocryphal continuation of Cleveland suggests an ambivalent attitude toward this kind of quasi-collaborative authorship. ${ }^{14}$ Prevost's contrasting responses to what seem -to modern readers-identical actions reveal a shift in ideas about what it means to be an author. The modern conception of the relationship between authors and their work requires a transfictional text either to completely modify or completely preserve the original author's vision of the transfictional elements. Mauvillon's text follows an inbetween course; for example, it neither completely reduces the count to a shallow character dominated by mercenary concerns, as Tremewan has claimed (1978: 331-32), nor fully maintains Prevost's count's complexity. Finally, whereas modern readers might expect Mauvillon to modify either the character of the count or his environment, but not both, Mauvillon does just that, emphasizing some pre-existing characteristics, downplaying others, adding some new ones, and introducing new characters while reframing the narrative structure.

\section{Can the Middle be the End?}

9 Though middle and end seem mutually exclusive, Prévost's and Mauvillon's Mémoires suggest otherwise, illuminating narrative structure as a source of eighteenth-century transfictionality. To understand how Mauvillon shifts narrative and dispositive boundaries, we must review the narrative material contained in the two installments. While Prévost's text makes up a large portion of Mauvillon's text, the plots expressed by each version reveal two unique underlying narrative structures. Both versions consist of the retrospectively narrated memoirs of an unnamed count, the titular honnête homme. ${ }^{15}$ Prévost's count narrates his introduction to Parisian society, including an unhappy love affair with a married woman, Mme de B...; an attempt to save a prostitute named Fanchon from infamy; and a forced deathbed marriage to his spurned provincial lover, Mlle de St. V.... Now imprisoned in Austria, the count gives the memoirs he writes to the frame narrator, a tutor who visits the count in prison while accompanying a young nobleman traveling through Europe, on the condition that he promise to publish them only after the death of an unnamed woman involved in the story. Ending with a deathbed marriage, Prévost's version leaves open when and how the count was imprisoned, and whether he survives. In Mauvillon's version, the count survives a brief imprisonment; he becomes increasingly passive, encountering new characters with designs on him (a gold-digging mother-daughter duo) or who seek his help (Mlle Ursule, hoping to avoid prostitution); and he experiences love affairs whose unhappy conclusions lead to retirement from active life. ${ }^{16}$ 

exemplifies the narrative-dispositive interplay possible under eighteenth-century conditions of production and distribution. Tremewan discusses this decision as one consideration in the complex question regarding Prévost's intention (or lack thereof) to continue the work (1978: 40-62); my analysis highlights its generativity. Placing a deathbed scene at a dispositive boundary (the end of the installment) balances readerly desire for a narrative arc within the material confines of the text available at a given point in time (the installment) and the author's need to preserve both readerly interest in a continuation of the narration and the narrative possibility of such a continuation. The relative clumsiness of Mauvillon's revival of the count, healed by a quasimiraculous remedy, may indicate less technical expertise, but not Prévost's abandonment of the text. In Prévost's original text, the end of the first installment concludes a narrative structure, yet-in Mauvillon's expanded version-that "end" functions simply as one of many "middles," or intermediary narrative structural transitions. ${ }^{17}$ Whereas transfictionality in modern texts requires an end to establish a boundary to transgress, Mauvillon's continuation of Prévost's text suggests that such transgressions are merely a specific instance of a more general case: a shift in relationship between narrative and dispositive structures.

Interactions between narrative and dispositive boundaries within the first installment show how Prévost adds detail and complexity to each additional phase of the dialectic process. For example, Prévost's second major narrative unit amplifies and problematizes the first major narrative unit's dialectic juxtaposing the count's naïveté (thesis, first subunit), his apparent sophistication (antithesis, second), and the synthetic view of some forms of sophistication as new forms of naïveté (third). The first book ends here. Comparing the progress thus far in the dispositive structure (half of Prévost's two-book installment, or a quarter of a potential four-book work) to progress in the narrative structure (less than half completed) reveals the gradually dilating effect of Prévost's narrative pattern. A dialectical structure has two key points of transition: between thesis and antithesis, and between antithesis and synthesis. To allow the dispositive boundary of the first installment to signal its completeness, the end of the first major narrative unit should have coincided with the beginning of a new book. Because the most significant dispositive boundary of the first installment coincides instead with the halfway point of the narrative structure, however, Prévost's readers begin the second book with the "weight" of half of the narrative structure behind them, enhancing the sense of completion at the end of the second book (also the end of the first installment) without requiring definitive closure.

12 In fact, the first installment is incomplete with respect to both promised events and narrative structure, leaving open the option of a continuation. As Prévost's text closes, the reader has yet to discover how the count ended up in prison, how he could have written the memoir as it stands, and how he could then have given it to the editor. Such openness insures that Mauvillon could have published a stand-alone second installment of the work without straining the narrative structure of Prévost's text; such a work would have been transfictional by modern, but not eighteenth-century criteria. Instead, Mauvillon's continuation superimposes a new narrative structure onto Prévost's text, suggesting not simply a desire to profit from another's work, but an independent aesthetic motivation. Prévost's installment ends before the second major narrative unit concludes, and it is this lack of coincidence that enables Mauvillon's 
transformation of Prévost's narrative structure, and thus the creation of a transfictional work. Furthermore, in Mauvillon's version the end of the first installment does not coincide with a major narrative structural transition; rather, the constraints of contemporary modes of production and distribution both emphasize the dispositive transition between the two installments and simultaneously insist on the connection between them: these opposed techniques produce an eighteenth-century transfictional text.

13 The links between the two parts of the work call attention to the establishment and transgression of narrative boundaries, especially those created by inserting new material into Prévost's text. In Prévost's version, an incomplete narrative synthesis is signaled by a transition into what is both the end of the second major narrative unit and the beginning of a potential third major unit (at the end of the second book). Mauvillon's continuation actualizes this potential, providing a third and final major narrative unit, but it follows a linear path, rather than continuing the unfinished cyclical narrative structure of Prévost's text, tracing the count's transitions from active agent of his narrative to passive object of others' volition. The count's agency wanes as he abandons his pursuit of his desired marriage partner, submits to others' efforts to marry him off to a countess for whom he feels no deep affection, and finally attributes the esteem in which the countess holds him to his friends' efforts rather than to his own merit. Mauvillon's narrative structure turns ends into middles by superimposing a linear trajectory onto Prévost's dialectical one, calling attention to the boundaries it transgresses.

14 While both versions of the text contain a dispositive boundary that must be surpassed for the narrative structure to reach completion, Mauvillon's modifications to Prévost's original change the method for bridging the gap between the two installments. Prévost's dialectical progression, with its increasing amplitude, provides an appropriate level of narrative satisfaction at the end of the first installment. By locating an important dramatic event at a significant dispositive transition, without locating the "halfway point" of the narrative structure there, Prévost leaves himself multiple options: to extend the narrative structure in several future installments, to bring it to a (provisional) conclusion in just one more installment, or to leave the text where it is. No choice would overly disappoint the reader. Mauvillon modifies the text to suit his purposes: his continuation, while avoiding siting the "halfway point" of the narrative structure at the most important point of transition in the dispositive structure, nonetheless creates an alternative narrative structure.

15 Key to Prévost's narrative structure is the evolution of the count's trust in the connection between truth and appearance and his understanding of that connection. This structure ultimately reconciles the count's two perspectives on himself, posing not merely the situational question of how he ended up in prison, but the moral one of how the once-young count came to see himself as the narrating older count does. In contrast, the new structure created by Mauvillon's additions highlights the work's interrogation of the concept of the honnête homme, and foregrounds the importance of financial and martial metaphors for social interaction. In Mauvillon's version, the first major narrative unit moves the count toward agency in response to the reactive goal of avoiding Mlle de St. V...; the second increases his agency in response to the proactive goal of pursuing Mme de B...; and in the third, the count's agency begins to wane as he responds to the proactive but unsuccessful goal of pursuing Lizon. While Prévost's 
structure elucidates the count's evolving attitude toward the relationship between reality, perception, and appearance, and is therefore punctuated by lessons and tests that mark dialectical shifts, Mauvillon's structure, based on the count's attitude toward true value and exchange value, is punctuated by changes in relationships that propel the count on a linear path. Mauvillon's addition of romantic intrigues does not rule out continuation in the spirit of Prévost's original version. In fact, it is possible to interpret Prévost's text either as a short-circuited whole or as an open fragment (Tremewan 1978: 40-62). However, this binary ignores the possibility of an intermediate state enabled by eighteenth-century modes of publication and distribution. This indeterminacy with respect to the completion of the work fostered a corresponding indeterminacy with respect to the ownership and the identity of the work as well.

\section{Sketching Narrative Contours}

16 Uncertain ownership and control of boundaries is manifest in Mauvillon's modifications to Prévost's introduction. In these introductions, each author distinctively guides his audience's interpretation of the narrative structure in a context in which a continuation would always be possible, whether by his own hand or someone else's. Prévost's count begins with a reference to an undefined future:

Je sors d'un profond cachot [...]. J'y étais attaché contre le mur par une grosse chaîne [...]. Ceux de qui j'ai reçu ce cruel traitement, m'ont supposé des crimes que j'ignore. Ils ne me les feront jamais mieux connaître, car mon cœur ne se reproche rien. J'aurai toute ma vie, pour fidèle escorte, l'infortune et l'innocence. (211) ${ }^{18}$

This reflection, implying an open-ended narration, envisions a future much like the present. ${ }^{19}$ Soon the count asserts that he has lost hope of ever being freed: he expects to spend the rest of his life in prison. In terms of narrative structure, then, the conclusion of this narrative has already occurred: the end of the count's story can only come with his death.

The count lays out his life story, describing two views of the path to the situation in which he begins to write his memoirs. Each provides a lens for reading the text that highlights a different aspect of the work's narrative structure. The first view, the count's self-evaluation, is the fruit of an internal process:

Un goût, peut-être outré, de la vérité et de la justice, joint malheureusement aux

faiblesses d'un cœur trop tendre, a causé toutes les infortunes de ma vie. Je suis parvenu à pouvoir peindre ainsi mon caractère d'un seul trait. Mais de quelles épreuves et de combien d'années n'ai-je pas eu besoin pour me le développer à moimême? (212) ${ }^{20}$

This portrait of the count's character invites readers to evaluate the accuracy of his retrospective conclusion, and to identify how he came to it. The second view, provided by his childhood tutor, also evokes a sustained encounter between two opposed forces, but questions the likelihood of any continuing equilibrium:

Un homme sensé, qui se trouvait chargé de mon éducation, observant avec quelle vivacité je me livrais au plaisir et combien il était facile néanmoins de me rappeler à la sagesse, ne se lassait pas de répéter qu'entre deux penchants si déclarés, qui ne pouvaient être longtemps de la même force, celui qui emporterait la balance irait nécessairement à l'excès ; ou s'ils conservaient quelque égalité, j'étais né pour être le plus malheureux de tous les hommes. C'est la seconde de ces deux prédictions qui s'est vérifiée. $(212)^{21}$ 
This view invites the reader to evaluate whether the count remains equally susceptible to his penchants for pleasure and for good behavior. While the count's view projects stasis, the tutor's view presents stasis as untenable: only the count's penchant toward pleasure is spontaneous, his penchant toward good behavior requiring external stimulation. Although the tutor's prediction invites identification of such external reminders, and the count's invites attention to iterations of equilibrium, both enable an open-ended narrative.

Mauvillon's modifications to the introduction forecast narrative restructuring. Whereas Prévost's narrator outlines an unchanging future course; Mauvillon's expects a definitive change:

Si la méchanceté de mes ennemis l'emporte sur mon innocence, jusqu'au bout, je croirai que la providence a des raisons particulieres [sic] qu'il ne m'appartient pas

d'examiner. Mais j'ai tout lieu de croire que mes malheurs vont finir, ou du moins s'adoucir. (2) 22

While Prévost collapses the uncertainty of the narrative's eventual outcome yet leaves the path open, Mauvillon allows doubt about the outcome and focuses on subjective analysis of the path. Mauvillon's second addition to the introduction heightens the text's commentary on social class (3-4), while the third talks about imprisonment leading to a lack of distinction between past, present, and future (6), which could be an oblique reference to the broken chronology of Mauvillon's version of the text.

The introduction evokes different narrative horizons, revealing each text's distinctive narrative structure, despite the extent of common material. ${ }^{23}$ The dialectical narrative structure of Prévost's text can be discerned almost from the very beginning, its pseudofractal nature becoming increasingly clear. By modifying Prévost's text, Mauvillon creates a transfictional work out of a preexisting fiction by superimposing on its dialectical narrative structure a new narrative structure based on the protagonist's linear progression in personal agency as reflected in a series of unhappy love affairs.

\section{Can a Single Text Have Multiple Beginnings?}

Differences between Prévost's and Mauvillon's narrative structures are signaled by the open-endedness of the first installment, changes in the introduction, and the two versions' treatment of transitions between narrative and dispositive boundaries, such as the shape of the first major narrative units. Given the interpretive framework of the introduction, the first major narrative unit of Prévost's text contains the work's dialectical narrative structure in miniature, including the way it intersects with the text's dispositive structure in conjunction with the second major unit. Mauvillon's version of the "same" text lays the foundation of a linear narrative structure by means of a few strategic additions.

21 The first major unit of Prévost's text establishes a dialectical structure. It communicates the thesis that initiates the work's narrative movement: accurate perception of reality can lead to social satisfaction, an idea that the text's introduction suggests would have been transformed into the utter rejection of perception in favor of internal reality, had Prévost brought his dialectical narrative structure to completion. Although the count believes himself adequately prepared, his social education prior to arriving in Paris is insufficient, and he fails to negotiate the disparity between appearance and reality in Parisian society. This failure leads to the narrative antithesis: 
while the count's perception of reality may be faulty, those who are more socially adept may still convey inaccurate information; the count must learn to seek out trustworthy sources.

Prévost's second narrative subunit expresses the antithesis of the work's first dialectical process, the idea that substituting truth for rumor can correct the errors of society. By demonstrating the count's reception of conflicting information, this episode functions as the synthesis of the previous subunit; by demonstrating his incomprehension of the degree to which deception and distortion shape Parisian society, the episode functions as the thesis of the new narrative subunit. In turn, the second narrative episode expresses the second subunit's antithesis: the lies of a given social circle resist correction, because its function as a social network depends on the willful disregard of truth. The synthesis of the work's first dialectical process follows (third narrative subunit): finding the right social circle might enable the count to overcome his educational deficits. As the count then learns an embarrassing truth and refrains from correcting others' false views, his forbearance demonstrates that he has learned that sometimes revealing the truth can be as harmful as a lie. As thesis of a new subunit, this part of the narrative provokes a new antithesis: scrupulous honesty is to be maintained at all costs, even when doing so could compromise another person's honor.

In contrast to Prévost's initial establishment of a generative circular dialectic narrative structure, Mauvillon establishes a linear structure. In the first major narrative unit as modified by Mauvillon, the count gains independence through reacting to others, a step toward identifying personal, active priorities. More important, Mauvillon's count subsequently traces a linear path from social instruction to exposing his innocence. Whereas Prévost's count circles back to learn belatedly about untrustworthy appearances from gossip in Paris, Mauvillon's count is forewarned of the doubtful nobility of a mother-daughter pair of arrivistes whom he encounters (in a narrative addition) while en route to Paris. Mauvillon's first narrative subunit turns the narrative structure of Prévost's text inside-out: the dialectical narrative structure of Prévost's version-based on a repeated cycle of innocence, instruction, application, and disillusionment-is transformed into a linear progression from reactivity, to proactivity, and ultimately to passivity. Whether Mauvillon intended to transform Prévost's original narrative structure or to refigure the count as an honnête homme, the value of that term is evacuated by the way Mauvillon writes the character, an evacuation resulting from a modified narrative structure.

\section{Conclusion}

24 My analysis of transfictionality in Mémoires illuminates the complexity of the relationship between Mauvillon's and Prévost's versions of the text, and the differences between eighteenth-century and modern aesthetics. While Mauvillon's actions do not provide an example of what Saint-Gelais calls the mobility of myths in premodern narrative fiction, they do illustrate an economy of imagination connecting phenomena as disparate as fan fiction, the prose Arthurian vulgate cycle, and Homer's epics (2011: 534). This case of eighteenth-century French transfictionality provides evidence of the transition away from a period when the imagination upon which the economy was based allowed significant overlap between the zones of influence of its agents, a phenomenon 
that is reappearing today, spurred by growing ease of collaboration and appropriation. My analysis reinforces our understanding of the eighteenth century as an ambiguous moment during which authorial ownership corresponds neither to premodern nor modern conceptions. My analysis also suggests that eighteenth-century transfictionality, as exemplified by the Mémoires, depends not on material boundaries between works, or on a new writer's use of another's material, but on retroactively reconfiguring the relationship between dispositive and narrative boundaries. Thus, my analysis can spur future research on modern and eighteenth-century aesthetic similarities. Just as today's fans of serialized fiction enjoy looking for retcons (details added in later installments to explain inconsistencies or other narrative difficulties), ${ }^{24}$ eighteenth-century readers may have derived pleasure from comparing expanded works to their original versions. Mauvillon's title supports such a hypothesis by emphasizing not only additional material, but also changes within the original and the involvement of a new "editor." Furthermore, while resembling television reboots, ${ }^{25}$ Mauvillon's modifications within Prévost's text might have given readers the extra pleasure of seeing a character voicing a reader's objections and concerns. Finally, such comparisons should spur further study of premodern transfictionality.

\section{BIBLIOGRAPHY}

Blaise, Marie, 2007, “'Et Percevaus redit tot el' Translatio médiévale et transfictionnalités modernes," in R. Audet and R. Saint-Gelais (eds.), La Fiction, suites et variations, Rennes, PUR, p. 3151.

Brewer, Daniel, 2013, "Authors Present and the Experience of the Past," Romanic Review, vol. 103, nos. 3-4, p. 285-301.

Coulet, Henri, 2000, “Le monde falsifié de Prévost," in R. A. Francis and J. Mainil, (eds.), L'Abbé Prévost au tournant du siècle, Oxford, Voltaire Foundation, p. 291-304.

Démoris, René, 2011, "Questions de partition chez Marivaux et Mouhy," in M. Escola et al. (eds.), La Partie et le Tout : la composition du roman, de l'âge baroque au tournant des Lumières (Actes des colloques de Paris, Bruxelles et Venise, automne 2008), Leuven, Peeters, p. 443-56.

Dionne, Ugo, 2008, La Voie aux chapitres : poétique de la disposition romanesque, Paris, Seuil, coll. "Poétique."

Dionne, Ugo, 2009, "Livres et chapitres : la division du roman des lumières," in P. Stewart and M. Delon (eds.), Le Second Triomphe du roman du XVIII siècle, Oxford, Voltaire Foundation, p. 127-50.

Dionne, Ugo, 2011, "Le Roman : vue en coupe. Remarque sur la construction romanesque classique à partir des Effets surprenants de la sympathie," in M. Escola et al. (eds.), La Partie et le Tout : la composition du roman, de l'âge baroque au tournant des Lumières (Actes des colloques de Paris, Bruxelles et Venise, automne 2008), Leuven, Peeters, p. 413-30.

Duquaire, Alexandre, 2006, Les Illusions perdues du roman : l'abbé Prévost à l'épreuve du romanesque, Amsterdam, Rodopi. 
Escola, Marc, 2011, "Le clou de Tchekhov. Retours sur le principe de causalité regressive," in M. Escola et al. (eds.), La Partie et le Tout : la composition du roman, de l'âge baroque au tournant des Lumières (Actes des colloques de Paris, Bruxelles et Venise, automne 2008), Leuven, Peeters, p. 107-17.

Frautschi, Richard L., 2000, "Les Mémoires d'un honnête homme et sa suite, ou le dédoublement du double registre," in R. A. Francis and J. Mainil (eds.), L'Abbé Prévost au tournant du siècle, Oxford, Voltaire Foundation, p. 305-17.

Friedenthal, Andrew J., 2017, Retcon Game: Retroactive Continuity and the Hyperlinking of America, Jackson, UP of Missisippi.

Griffin, Robert J., 2005, “The Text in Motion: Eighteenth-Century Roxanas,” English Literary History, vol. 72, no. 2, p. 387-406.

Genette, Gérard, 1982, Palimpsestes : la littérature au second degré, Paris, Seuil, coll. "Points essais."

Harries, Elizabeth Wanning, 1994, The Unfinished Manner: Essays on the Fragment in the Later Eighteenth Century, Charlottesville, UP of Virginia.

Hartmann, Pierre, 2002, "La réception de Paméla en France : Les Anti-Paméla de Villaret et Mauvillon," Revue d'histoire littéraire de la France, no. 102, p. 45-56.

Hirschfeld, Heather, 2001, "Early Modern Collaboration and Theories of Authorship," PMLA, vol. 116, no. 3, p. 609-22.

Hunter, J. Paul, 1997, "Serious Reflections on Farther Adventures: Resistances to Closure in Eighteenth-Century English Novels," in A. J. Rivero (ed.), Augustan Subjects: Essays in Honor of Martin C. Battestin, Newark, U of Delaware P, p. 276-94.

Jenkins, Henry, 2006, Convergence Culture: Where Old and New Media Collide, New York, New York UP.

Kermode, Frank, [1967] 2000, The Sense of an Ending: Studies in the Theory of Fiction, Oxford, Oxford UP.

Lavocat, Françoise, 2007, “Transfictionnalité, métafiction et métalepse aux XVI ${ }^{\mathrm{e}}$ et XVII ${ }^{\mathrm{e}}$ siècles," in R. Audet and R. Saint-Gelais (eds.), La Fiction, suites et variations, Rennes, PUR, p. 157-78.

Leborgne, Erik, 2011, “Un cas de roman prolongeable : L'Infortuné Napolitain et ses suites (1708, 1721)," in M. Escola et al. (eds.), La Partie et le Tout : la composition du roman, de l'âge baroque au tournant des Lumières (Actes des colloques de Paris, Bruxelles et Venise, automne 2008), Leuven, Peeters, p. 431-42.

MacArthur, Elizabeth J., 1987, “Devious Narratives: Refusal of Closure in Two Eighteenth-Century Epistolary Novels," Eighteenth-Century Studies, vol. 21, no. 1, p. 1-20.

Michie, Allen, 2007, "Far From Simple: Sarah Fielding's Familiar Letters and the Limits of the Eighteenth-Century Sequel," in D. Bourdeau and E. Kraft (eds.), On Second Thought: Updating the Eighteenth-Century Text, Newark, U of Delaware P, p. 83-111.

Miller, David A., 1981, Narrative and Its Discontents: Problems of Closure in the Traditional Novel, Princeton, Princeton UP.

Mittell, Jason, 2006, "Narrative Complexity in Contemporary American Television," The Velvet Light Trap, vol. 58, no. 1, p. 29-40.

Pacini, Giulia, 2005/2006, "Righteous Letters: Vindications of Two Refugees in Lettres d'une Péruvienne and Its Unauthorized Sequel, Lettres taïtiennes," Eighteenth-Century Fiction, vol. 18, no. 2, p. 169-85. 
Principato, Aurelio, 2000, "L'honnête homme' et les sociétés mondaines autour de 1745," in R. A. Francis and J. Mainil (eds.), L'Abbé Prévost au tournant du siècle, Oxford, Voltaire Foundation, p. 33-46.

Saint-Gelais, Richard, 2011, Fictions transfuges : la transfictionnalité et ses enjeux, Paris, Seuil, coll. "Poétique."

Seager, Nicholas, 2009, "Prudence and Plagiarism in the 1740 Continuation of Defoe's Roxana," Library: The Transactions of the Bibliographical Society, vol. 104, no. 12, p. 357-71.

Stewart, Philip, 1975, "Prévost et son Cleveland : essai de mise au point historique," Dix-huitième siècle, no. 7, p. 181-208, http://people.duke.edu/ pstewart/pescleve.htm.

Stewart, Philip, 1977, "Sur la conclusion du Cleveland de Prévost : l'influence de la suite apocryphe," Revue de littérature comparée, no. 51, p. 54-58.

Traver, John C., 2007, "The Sense of Amending: Closure, Justice, and Eighteenth-Century Fictional Sequel," PhD diss., Notre Dame U, ProQuest no. 3406932, https://curate.nd.edu/downloads/ 9c67wm1392d.

Tremewan, Peter J., 1978, "Prévost's Mémoires d'un honnête homme: A Critical Edition," PhD diss., U of Canterbury, Christchurch, New Zealand, http://hdl.handle.net/10092/4939.

Tremewan, Peter J., 1982, "Narrative Point of View in Prévost's Mémoires d'un honnête homme," Studies on Voltaire and the Eighteenth Century, no. 205, p. 45-56.

Tremewan, Peter J., 1990, “Character and Theme: The Binary Gentlemen of Prévost's Mémoires d'un honnête homme (1745)," Nottingham French Studies, vol. 29, no. 2, p. 64-71.

Turnovsky, Geoffrey, 2010. The Literary Market: Authorship and Modernity in the Old Regime, Philadelphia, U of Pennsylvania P.

Urbanski, Heather, 2013, The Science Fiction Reboot: Canon, Invention, and Fandom in Refashioned Franchises, Jefferson, NC, McFarland.

Vanacker, Beatrijs, 2011, “Comment le 'tout' peut réinvestir la 'partie' : à propos du triptyque romanesque des heureux orphelins," in M. Escola et al. (eds.), La Partie et le Tout : la composition du roman, de l'âge baroque au tournant des Lumières (Actes des colloques de Paris, Bruxelles et Venise, automne 2008), Leuven, Peeters, p. 467-79.

\section{Corpus}

Mauvillon, Éléazar de, 1753, Mémoires d'un honnête homme, revûs [sic], corrigés, augmentés d'un second volume, et imprimés sur un nouveau manuscrit de l'auteur, publié par M. de $M^{* * * * *}$, Dresden, Georges Conrad Walther, Google Books.

Prévost, Antoine-François, [1745] 1986, Mémoires d'un honnête homme, in J. Sgard et al. (eds.), CEuvres de Prévost, vol. VI, Grenoble, Presses universitaires de Grenoble.

Prévost, Antoine-François, 1748, Memoirs of a man of honour: Containing an exact Description of the Polite Assemblies at Paris, their Modes of Conversation, Ways of Living, their Pleasures, Entertainments, $\& c$. Intermixed with several Interesting and pleasant Stories. Written for the Instruction and Amusement of all who would know the World, London, John Nourse, Google Books. 


\section{NOTES}

1. These can be rendered in English as "the material independence of the texts, the independence of the stories, and the involvement of a new author."

2. Françoise Lavocat's study of transfictionality in seventeenth- and eighteenth-century fiction opposes intraleptic and metaleptic texts, the first being concerned with avoiding logical inconsistencies and thereby only implicitly metatextual, the second clearly violating such rules and thus overtly so. Lavocat argues that the difference between these types is one of kind, not degree: the overt logical inconsistencies of metaleptic transfictions take them into the realm of fairytale, thereby relieving them of ethical and ontological burdens (2007: 173-75).

3. Marc Escola (2011) coined the term "fiction périodique" (periodical fiction) for designating novels that "s'écrivent dans l'ignorance de leur fin" (are written without knowledge of their endings).

4. Despite the lack of direct narrative continuity between Fielding's The Adventures of David Simple (1744), her Familiar Letters between the Principal Characters in David Simple (1747), and David Simple: Volume the Last (1753), all three can all be taken together as forming a single fiction (Michie 2007). Mouhy's La Mouche, ou les aventures et espiègleries facétieuses de Bigand was published in several stages, the first part appearing in 1735, parts II through IV in 1736, and its Suite in 1742, but the text remains a single work despite certain centrifugal tendencies that might lead modern readers to distinguish the parts from each other (Démoris 2011).

5. Challe's Continuation de l'histoire de l'admirable Don Quichotte de La Manche (1713) acts as a sixth volume of the 1677 translation by François Filleau de Saint-Martin of Cervantes' El ingenioso hidalgo don Quijote de la Mancha (1605) and its Segunda parte (1615). Defoe's Roxana (1724) had six distinct continuations $(1740,1745,1750,1755,1765$, and 1775), each of which was incorporated into the body of the work (Seager 2009: 357-58). Graffigny's Lettres d'une Péruvienne (1747) inspired several continuations, including Lettres d'Aza ou d'un Péruvien (1749) and Lettres taïtiennes (1784), which were presented as separate works (Pacini 2005/2006: 171, 181-85). Marivaux's famously unfinished La Vie de Marianne (1731-1742) inspired three continuations: one appeared in 1739, during a publication hiatus; another appeared in 1745, after Marivaux had abandoned the work; and the only one of known authorship, Riccoboni's Suite de la vie de Marianne (1761), was at first mistaken for the work of the original author. The case of L'Infortuné Napolitain is particularly complex, beginning with the initial two-part installment of 1704 and its 1708 Suite, both anonymous, followed by a pirated edition combining the first three parts in 1709, continuing with the Abbé Olivier's 1721 two-part continuation, Nouvelles aventures de l'infortuné Napolitain, which was in turn followed by another collected edition containing all five parts in 1729 (Leborgne 2011). Crébillon's Les Heureux orphelins (1754) is a modified translation and a continuation of Eliza Haywood's Fortunate Foundlings (1744) (Vanacker 2011).

6. Prévost's Cleveland is the prototypical example of this phenomenon: Prévost took so long to finish the work that his publisher hired another writer to do it for him; and even so, Prévost later wrote a conclusion of his own (Stewart 1975). Another notable instance, Richardson's Pamela, is especially relevant to the context of this article, since one of the multiple parodies it inspired, written by Eliza Haywood, was translated by Mauvillon (Hartmann 2002: 49-55).

7. See Harries (1994), Hunter (1997), Griffin (2005), MacArthur (1987), and Traver (2007) for further discussion of closure in pre-nineteenth-century prose fiction. See Miller (1981) for an investigation of resistance to closure in nineteenth-century novels.

8. Studies of Mémoires d'un honnête homme include Coulet (2000), Duquaire (2006), Frautschi (2000), Principato (2000), and Tremewan (1982, 1990). Only Frautschi focuses on comparing Mauvillon's version to Prévost's, which he does via comparative analysis of the two authors' use of two axes of narration: the narrating axis (l'axe narrant) and the narrated axis (l'axe narré), as well as some semantic analysis. 
9. Some translations of the Mémoires highlight the complexity of contemporary authorial attribution: the text of Mauvillon's continuation was published alone in German translation in 1754, and was sometimes bound together with an earlier (1746 or 1747) translation of Prévost's unmodified text that included an attribution to the author of Cleveland, while an Italian translation contained both Mauvillon's modified version of Prévost's original text and his continuation, but made no mention of Prévost, including only an anonymized attribution to Mauvillon (Tremewan 1978: 339-40, 343, 348-49).

10. Here and elsewhere, I have retained the original spelling of Mauvillon's text, which has not been republished in a modern edition.

11. The title page of the Prévost's original version mentions no editor.

12. Dionne establishes a typology of disposition in La Voie aux chapitres (2008). Elsewhere, he attends to some of the elements of narrative structure, but privileges formal elements of the text $(2009,2011)$.

13. Escola discusses compositional strategies required under such circumstances (2011).

14. Indeed, even in the case of Cleveland, Prévost may have taken inspiration from the writer who continued his work without his authorization (Stewart 1977).

15. The term honnête homme designates an individual who embodies a constellation of aristocratic virtues, far beyond what we mean by "honest." The idea of honnêteté played an important role in constituting authorial identity in the early modern period (Turnovsky 2010, Brewer 2012), and in Prévost's reevaluation of his work as an author toward the end of his career (Duquaire 2006).

16. In Mauvillon's version, the count's amorous obstacles both explain his imprisonment in Austria and motivate his desire to retire from active life, spurred by the death of his son after that of his first wife.

17. Frautschi also notes this contrast (2000: 317-18).

18. "I come from a deep and horrid dungeon, where I [was] fastened to the wall by a huge chain [...]. Those from whom I received this cruel treatment, have supposed me guilty of crimes of which I am ignorant: I have only suffered for want of being better known; for my heart has nothing wherewith to reproach itself: - Innocence and ill-fortune have been the inseparable companions of my whole life." (1) A translation of Prévost's text appeared in London in 1747. Having been unable to examine the first edition of this translation, I have cited the second edition, which appeared the following year. The anonymous translator has rendered "[i]ls ne me les feront jamais mieux connaître" as "I have only suffered for want of being better known," but a more accurate version would be "they (i.e. the count's accusers) will never cause me to better understand them (i.e. the crimes of which they accuse me)." This change shifts the original version's focus on the count's internal self-examination onto an external recognition of his identity.

19. The translator reverses this effect by using the present perfect ("have been") to translate the future tense ("J'aurai toute ma vie") of the original.

20. "[A] love, perhaps, beyond measure of truth and justice, unhappily joined with the weakness of a heart too tender, has occasioned all the calamities of my life: my whole character is comprehended in these words, and the proofs of many years has sufficiently shewn [sic] me, I have no necessity of examining farther into myself." (5-6) The beginning of the first sentence will perhaps make more sense to a modern reader punctuated thus: "[A] love, perhaps beyond measure, of truth and justice [...]."

21. "[A] man of great understanding in human nature, who had the care of my education, observing that I gave myself up to pleasure with the utmost eagerness and vivacity, yet, nevertheless, nothing was more easy than to recover me into the most serious reflections, used frequently to say, that between two inclinations so different, which ever got the better, would certainly be carried to a very great excess; and if any equality was preserved, I must be born to be the most unfortunate of all men; which last prediction has been but too sadly verified." (6) The 
translator exaggerates the text's finality by adding an affirmation of the lack of need for continued introspection.

22. "If the wickedness of my enemies continues to win out over my innocence until the very end, I will take it as a sign that Providence has specific motives [for allowing this to happen] that are not mine to question. But I have every reason to believe that my woes are going to come to an end, or at least diminish." (In the absence of an English edition of Mauvillon's version of the work, I have provided my own translation of this passage.)

23. Frautschi also comments on the distinction between the "closed" narrative structure of Mauvillon's version of the work and the "open" structure of Prévost's (2000: 317-18).

24. For a study of the phenomenon of the retcon, see Friedenthal (2017).

25. For a discussion of the reboot as part of a larger trend toward more sophistication in television, see Mittell (2006). For a study of the phenomenon within the science fiction genre, see Urbanski (2013).

\section{ABSTRACTS}

While scholars generally use the concept of transfictionality to describe narrative crossover between separate works, this limitation does not apply in the eighteenth century, when publication in multiple installments and evolving ideas about the concept of copyright made created transfictional relationships within individual works. Comparative analysis of Prévost's Mémoires d'un honnête homme and its continuation by Éléazar de Mauvillon shows that neither the text's plural authorship nor the material separation of its parts suffice to determine the transfictionality of this textual ensemble. Rather, Mauvillon created a transfictional work by modifying the relationship between the narrative structure of Prévost's text and its dispositive structure (books, volumes, installments).

Bien que la transficionnalité soit un concept généralement employé pour rendre compte d'emprunts de matière fictionnelle entre œuvres indépendantes, cette limitation ne devrait pas s'appliquer au XVIII ${ }^{\mathrm{e}}$ siècle, époque où la publication par parties séparées et l'évolution du privilège et $\mathrm{du}$ droit d'auteur rendaient possible l'existence de relations tranfictionnelles à l'intérieur même d'une seule œuvre. L'analyse comparative des Mémoires d'un honnête homme de l'abbé Prévost et de sa continuation par Éléazar de Mauvillon montre que ni la pluralité des auteurs ni la séparation matérielle des parties ne détermine la transfictionnalité de cet ensemble textuel. Plutôt, Mauvillon a créé une œuvre transfictionnelle en modifiant la relation entre la structure narrative du texte de Prévost et sa structure dispositive (livres, tomes, parties).

\section{INDEX}

Mots-clés: fermeture, clôture, structure, transfiction, transfictionnalité, disposition, narration, partie, tout, feuilleton, retcon, reboot, dix-huitième siècle

Keywords: closure, structure, transfiction, transfictionality, disposition, narration, part, whole, serialization, retcon, reboot, eighteenth century 
AUTHOR

BENJAMIN H. BAKER

Villanova University 